\title{
Partitioning of rainfall into throughfall, stemflow, and interception loss in the Brazilian Northeastern Atlantic Forest
}

\author{
Jacques C. Ribeiro Filho', Luis C. de A. Lemos Filho², Julio C. N. dos Santos ${ }^{3}$, \\ José B. Brasil ${ }^{1} \&$ Helba A. de Q. Palácio ${ }^{4}$ \\ ${ }^{1}$ Universidade Federal do Ceará/Departamento de Engenharia Agrícola/Programa de Pós-Graduação em Engenharia Agrícola. Fortaleza, CE. E-mail: \\ jacquesfilho1@hotmail.com (Corresponding author) - ORCID: 0000-0001-9544-009X; josebbrasil@gmail.com ORCID: 0000-0003-4335-7838 \\ ${ }^{2}$ Universidade Federal Rural do Semi-Árido/Programa de Pós Graduação em Manejo de Solo e Água. Mossoró, RN. E-mail: lcalfilho@ufersa.edu.br - \\ ORCID: 0000-0001-8527-2686 \\ ${ }^{3}$ Instituto Federal do Triangulo Mineiro. Uberlândia, MG. E-mail: juliosantos@iftm.edu.br - ORCID: 0000-0001-9466-5158 \\ ${ }^{4}$ Instituto Federal do Ceará. Iguatu, CE. E-mail: helbaraujo23@yahoo.com.br - ORCID: 0000-0002-5105-4821
}

\begin{abstract}
Information on hydrology, and vegetation distribution is essential for the development of techniques and strategies to cope with droughts in semi-arid environments. The objective of this study was to evaluate the partitioning of gross rainfall into throughfall, stemflow, and interception loss in the Brazilian Northeastern Atlantic Forest, and its correlations with rainfall characteristics. The study was conducted in the Bica watershed, in Portalegre, state of Rio Grande do Norte, Brazil. The work was carried out in 2017, with monitoring of the throughfall, stemflow, and interception loss in an area of $10 \times 20 \mathrm{~m}$. Total rainfall depths (TRD) and wind speed were measured, and the evapotranspiration $\left(\mathrm{ET}_{0}\right)$ was estimated. Based on this information, the intensity (I), kinetic energy (KE) and intensity at intervals of 5, 10, 20, 30, 45, and 60 min of each rainfall event were measured. Twenty rainfall events occurred during the study period. The vegetation showed interception of $44.9 \%$, throughfall of $52.9 \%$, and stemflow of $2.2 \%$ of the total rainfall. Three principal components (PC) were formed in the PC Analysis, explaining more than $84 \%$ of the total variance. PC1, $\mathrm{PC} 2$, and PC3 encompassed variables related to rainfall energy to overcome the vegetation physical barrier, inflow and outflow, and variables dependent on the rainfall duration, respectively.
\end{abstract}

Key words: caatinga, hydrology, semi-arid, principal component analysis

\section{Particionamento da chuva pelo processo de interceptação vegetal no semiárido nordestino}

RESUMO: A compreensão do comportamento hidrológico e da distribuição da vegetação em um ambiente semiárido é fundamental para o desenvolvimento de técnicas e estratégias para a convivência com as secas. Objetivou-se com esse trabalho, quantificar o particionamento da precipitação pela vegetação caracterizada como Mata Atlântica Nordestina bem como suas relações com as características da precipitação. O estudo foi desenvolvido na Bacia da Bica, em Portalegre - RN. O trabalho foi realizado durante o ano de 2017, foram monitorados a precipitação interna, escoamento pelos caules das árvores e perda por interceptação em uma área de 10 x $20 \mathrm{~m}$. Com o auxílio de uma estação meteorológica realizou-se as medidas da precipitação pluvial (PPT) e a velocidade do vento e estimada a evapotranspiração (ETo). Com base nessas informações, calculou-se a intensidade (I) de cada evento, energia cinética (EC) e as intensidades em intervalos de 5, 10, $20,30,45$ e $60 \mathrm{~min}$ (I5, I10, I15, I20, I30, I45 e I60 respectivamente). No período de estudo foram registrados 20 eventos de chuvas. A vegetação reteve $44,9 \%$ da precipitação do total, enquanto $52,9 \%$ contribuiu com a precipitação interna e 2,2\% escoou pelos troncos. Com o auxílio de Análises das Componentes Principais, foram formadas três Componentes Principais (CP) explicando mais de $84 \%$ da variância total. Nas CP1, CP2 e CP3 foram enquadradas, respectivamente, variáveis relacionadas ao poder energético da chuva em ultrapassar a barreira física da vegetação, fluxo de entrada e saída e variáveis que mudam de acordo com o tempo de duração da chuva.

Palavras-chave: caatinga, hidrologia, semiárido, análise de componente principal 


\section{INTRODUCTION}

Arid and semi-arid regions have constant problems due to water scarcity (Dunkerley, 2008a, b; Zhang et al., 2016), and increasingly prolonged droughts. Information on hydrology, and vegetation distribution is essential for the development of techniques and strategies to cope with droughts in semi-arid environments (Zhang et al., 2015; Ribeiro Filho et al., 2017).

Rainfall interception by plants affects the water balance in the hydrological cycle, especially in forest areas in arid and semi-arid regions, where the water infiltrates into the soil or evaporates, and there is no underground water inflow (Dunkerley, 2008a; Linhoss \& Siegert, 2016). Rainfall in vegetated areas is naturally fractioned into interception loss - rain that is intercepted by vegetation and returns to the atmosphere by evaporation; throughfall - rain that passes freely through the vegetation, or splatters on leaves or branches, and reaches the ground; and stemflow - rain that is diverted by plant stems and reaches the ground through them (Giglio \& Kobiyama, 2013; Izídio et al., 2013).

The part of rain that is intercepted by vegetation is affected by meteorological elements, especially rainfall depth, duration, frequency, and intensity, and wind speed (Lloyd \& Marques, 1988; Medeiros et al., 2009; Lorenzon et al., 2013; CarlyleMoses et al., 2014). Hydrological studies have shown some rainfall properties, besides the conventional parameters, that provide information for the understanding of hydrological processes in arid and semi-arid regions, such as surface runoff, and interception loss (Dunkerley, 2008a; Figueiredo et al., 2016; Zhang et al., 2016).

Thus, the objective of this work was to evaluate the partitioning of gross rainfall into throughfall, stemflow, and interception loss in the Brazilian Northeastern Atlantic Forest, and its correlations with rainfall characteristics.

\section{Material ANd Methods}

The experiment was carried out in the Area of Relevant Ecological Interest of the Bica watershed in Portalegre, state of Rio Grande do Norte, Brazil. The landscape of this watershed is formed by perennial springs and a perennial waterfall, which increased the interest for its conservation. Figure 1 shows the

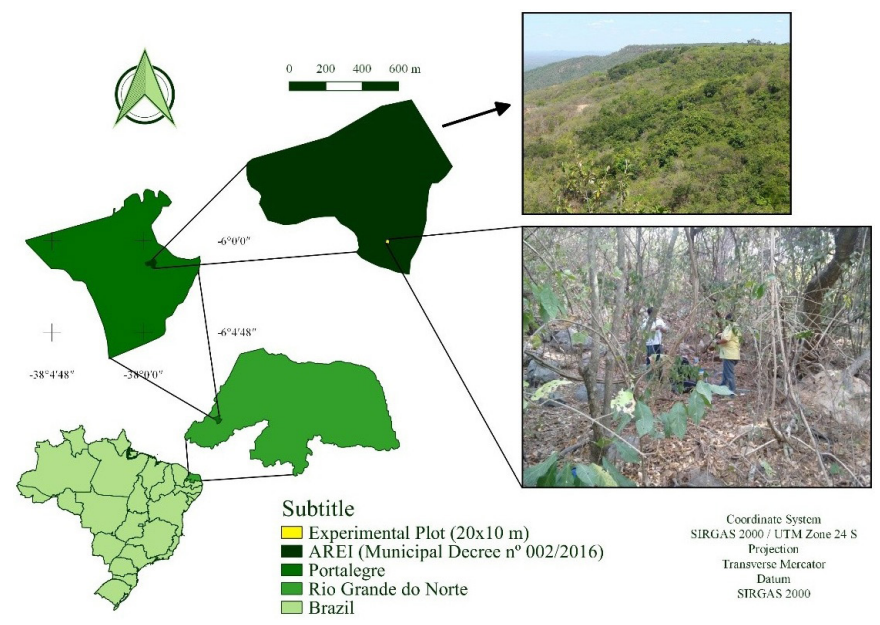

Figure 1. Location of the study area location of the Bica watershed in the State of Rio Grande do Norte, Brazil, and the experimental area used for measuring the partitioning of rainfall.

The Bica watershed is at $6^{\circ} 01^{\prime} 33.04^{\prime \prime} \mathrm{S}$ and $37^{\circ} 59^{\prime} 27.93^{\prime \prime}$ $\mathrm{W}$. The climate of the region is tropical rainy (Aw), according to the Köppen classification (EMPARN, 2017); the region is surrounded by Sertaneja Depressions; and considering the precipitation index, aridity index, and risk of droughts, the watershed is within the Brazilian semi-arid region (Brasil, 2017). The region presents average historical precipitation (1961 to 2016) of $973.8 \mathrm{~mm}$ (EMPARN, 2017), temperatures varying from 36.0 to $21.0^{\circ} \mathrm{C}$ and with average of $28.1{ }^{\circ} \mathrm{C}$, annual average relative humidity of $66 \%$, and annual insolation of 2,700 hours (IDEMA, 2008). The vegetation of the region consists of Brazilian native and endemic species that occur in the Caatinga, Cerrado, and Atlantic Forest biomes, and is classified as Northeastern Atlantic Forest (IDEMA, 2008; Dantas, 2016; Medeiros et al., 2016).

The study was conducted from January to December 2017, considering the rainfall depths (TRD), air temperature, wind direction and speed, duration of the rainfall event $(\mathrm{T})$, and estimated reference evapotranspiration $\left(\mathrm{ET}_{0}\right)$. These variables were monitored using an automatic meteorological station (WH-1080 PC, Instrutemp ', São Paulo, Brazil), equipped with a pluviograph that store data with five-minute intervals. The $\mathrm{ET}_{0}$ was estimated using the method proposed by Hargreaves \& Samani (1985). Based on the rainfall data, the intensity of the event (I), and the intensity at intervals of 5 (I5), 10 (I10), 20 (I20), 30 (I30), 45 (I45), and 60 (I60) min, and kinetic energy (KE) were measured, according to the methodology proposed by Foster et al. (1981).

The rainfall partitioning was monitored in a plot of $200 \mathrm{~m}^{2}$ $(20 \times 10 \mathrm{~m})$ in the Bica watershed. Collections were performed after each rainfall event. A Ville de Paris rain gauge and a handmade recipient were installed next to the experimental plot to measure the total rainfall depth. Ten containers made from pet bottles were installed at $1.5 \mathrm{~m}$ height inside the experimental plot, and calibrated using the Ville de Paris gauge, following the methodology proposed by Lloyd \& Marques (1988).

Seventy-one trees with circumference of 10 to $91.3 \mathrm{~cm}$ (mean of $9.6 \mathrm{~cm}$ ) were found in the experimental area; the Hymenaea Stigonocarpa species (Jatobá) presented the highest density, and $91 \%$ of species found were from the Caatinga phytogeographical domain, according to Dantas (2016). The trees were divided into 6 classes according to their stem circumferences, following the methodology adopted by Izídio et al. (2013). One tree of each stem circumference class was selected and a collector ring was attached to their trunk with epoxy resin and connected to an 18-liter closed container through a 0.75 -inche plastic hose to avoid evaporation when collecting the stemflow water.

The stemflow of all trees was determined for each rainfall event considering that the stemflow of all trees was equal to the that of the sampled tree in the same class, and the sum of the stemflow was calculated by the number of trees in each class, according to Eq. 1: 


$$
\mathrm{SF}=\sum_{\mathrm{I}=1}^{\mathrm{n}} \mathrm{SFi} \text { qi }
$$

where:

SF - stemflow calculated for each rainfall event $(\mathrm{mm})$;

$\mathrm{n}$ - number of trees in the circumference classes;

SFi - stemflow from the representative tree of the class i; and,

qi - number of trees of the class i.

The interception losses were estimated indirectly by the difference between the total rainfall depth and the amount of water reaching the soil, according to the methodology proposed by Carlyle-Moses et al. (2014), which was calculated using Eq. 2:

$$
\mathrm{IL}=\mathrm{TRD}-\left(\mathrm{T}_{\mathrm{I}}+\mathrm{SF}\right)
$$

where:

IL - interception loss ( $\mathrm{mm})$;

TRD - total rainfall depth $(\mathrm{mm})$;

$\mathrm{T}_{\mathrm{i}} \quad$ - throughfall, measured under the vegetation $(\mathrm{mm})$; and,

SF - stemflow (mm).

Statistical analysis of the data was carried out using the Statistical Package for the Social Sciences (SPSS) 16.0. The multivariate statistical model with hierarchical cluster analysis, and factorial analysis and principal component analysis (FAPCA) was used to identify the similarity and the determinants of the rainfall partitioning variability. The Tukey's test at 0.01 probability level was also applied.

Hierarchical cluster analysis was used to standardize $\mathrm{z}$-scores. The variables were standardized using the square Euclidian Distance to measure similarity, and the Ward binding algorithm using the variables: TRD, ET, Wind Speed (WS), Rainfal Intensity (RI), T, KE, I5, I10, I15, I20, I30, I45, and I60. The variables considered for the FA-PCA were TRD ( $\mathrm{mm})$; I (mm); I5, I10, I15, I20, I30, I45, and I60 $\left(\mathrm{mm} \mathrm{h}^{-1}\right) ; \mathrm{KE}\left(\mathrm{MJ} \mathrm{mm} \mathrm{h}^{-1}\right)$; $\mathrm{ET}_{0}\left(\mathrm{~mm} \mathrm{~d}^{-1}\right)$, WS $\left(\mathrm{m} \mathrm{s}^{-1}\right)$ and $\mathrm{T}$ (min.).

The original data were expressed as a matrix by $\mathrm{X}=\left(\mathrm{x}_{\mathrm{i}, \mathrm{j}}\right)$, where in $i=1 . . . n$ samples, and $j=1$...p variables. The first step when applying the FA-PCA was to transform the original matrix data into a correlation matrix $[R](p \times p)$, with $p$ equal to the 15 variables analyzed in the study. The main reason for using the correlation matrix is to eliminate the problem of different scales and units used to measure the variables. The efficiency of the new description of data by components will depend on the percentage of total variation of each component, which is represented by the eigenvalues (Moita Neto \& Moita, 1997).

The variables were verified after the definition of the correlation matrix to identify the most specific ones, since the PCA defines components that may explain the correlations. The overall consistency of the data was measured by the Kayser Mayer Olkim Index (KMO), which compares the magnitude of the correlation coefficients observed with the partial correlation coefficients (Andrade et al., 2007). A KMO $<0.5$ indicates that the model does not apply to the study data (Norusis, 1990). The selection of the number of components was extracted according to Norusis (1990); thus, only components with variance greater than one were considered. This criterion was chosen because any factor should explain a variance higher than that presented by a simple variable.

Even using the matrix of the components that were obtained in the extraction phase, in which the result describes the relationship between factors and individual variables, interpreting the results can be difficult. To overcome this limitation, an orthogonal transformation procedure by the Varimax method or simply rotation of the matrix of the factorial loads was used, generating a new matrix of factorial loads, which presents a better interpretation of the factors.

\section{Results AND Discussion}

The total rainfall depth was $466.7 \mathrm{~mm}$, with 20 rainfall events in the period studied (January to December 2017). It was below the average of the municipality of Portalegre $(973.8 \mathrm{~mm})$. The throughfall $\left(\mathrm{T}_{\mathrm{i}}\right)$, stemflow $(\mathrm{SF})$ and the interception losses (IL), presented correlations with the rainfall depths of 0.85 , 0.65 , and 0.69 , representing $59.2,2.4$, and $38.4 \%$ of the total rainfall depth (TRD), respectively. The IL varied from $9.9 \%$ $(11 / 02 / 2017)$ to $92.6 \%(02 / 10 / 2017$ and $03 / 11 / 2017)$ (Table 1). These IL were higher than those found in other studies in semi-arid regions, in which the mean interception ranged from 13.0\% (Medeiros et al., 2009) to 41.8\% (Silva, 2017). However, the study area is in the Northeastern Atlantic Forest, near perennial water courses, and presents typical floristic species of the Atlantic Forest (Dantas, 2016; Medeiros et al., 2016) and ciliary forests, which present higher interception of rainfall. Similar result was found by Lima \& Leopoldo (2000) in a ciliary forest in the Cerrado biome in Brazil, with $37.6 \%$ of the rainfall intercepted by the vegetation.

Sixteen rainfall events that contained the largest number of variables was selected to better understand the interception

Table 1. Total rainfall depth (TRD), throughfall $\left(\mathrm{T}_{\mathrm{i}}\right)$, stemflow (SF)

\begin{tabular}{|c|c|c|c|c|c|c|c|}
\hline \multirow{2}{*}{ Datas } & \multirow{2}{*}{$\begin{array}{c}\text { TDR } \\
(\mathrm{mm})\end{array}$} & \multicolumn{2}{|c|}{$\mathrm{Ti}$} & \multicolumn{2}{|c|}{ SF } & \multicolumn{2}{|c|}{ IL } \\
\hline & & $(\mathrm{mm})$ & (\%) & $(\mathrm{mm})$ & (\%) & $(\mathrm{mm})$ & (\%) \\
\hline 02/10/2017 & 4.6 & 0.3 & 7.2 & 0.0 & 0.2 & 4.2 & 92.5 \\
\hline $02 / 11 / 2017$ & 37.1 & 32.4 & 87.4 & 1.0 & 2.7 & 3.7 & 9.9 \\
\hline $02 / 12 / 2017$ & 9.9 & 4.7 & 47.5 & 0.2 & 1.9 & 5.0 & 50.6 \\
\hline $03 / 05 / 2017$ & 24.7 & 19.6 & 79.1 & 0.6 & 2.6 & 4.5 & 18.3 \\
\hline $03 / 10 / 2017$ & 15.5 & 11.0 & 71.5 & 0.4 & 2.4 & 4.0 & 26.1 \\
\hline $03 / 11 / 2017$ & 4.6 & 0.3 & 7.2 & 0.0 & 0.2 & 4.2 & 92.6 \\
\hline $03 / 13 / 2017$ & 43.9 & 25.1 & 57.2 & 0.8 & 1.9 & 18.0 & 40.9 \\
\hline 04/01/2017 & 23.5 & 16.5 & 70.2 & 0.4 & 1.9 & 6.5 & 27.8 \\
\hline $04 / 11 / 2017$ & 12.4 & 5.9 & 47.8 & 0.3 & 2.3 & 6.2 & 50.0 \\
\hline $04 / 12 / 2017$ & 6.2 & 1.7 & 28.3 & 0.1 & 1.9 & 4.3 & 69.7 \\
\hline $04 / 24 / 2017$ & 31.5 & 20.7 & 65.6 & 0.8 & 2.5 & 10.1 & 31.9 \\
\hline 05/04/2017 & 26.0 & 9.5 & 36.7 & 0.4 & 1.5 & 16.0 & 61.8 \\
\hline $05 / 11 / 2017$ & 23.5 & 13.9 & 59.3 & 0.5 & 2.2 & 9.1 & 38.6 \\
\hline 05/12/2017 & 19.2 & 14.0 & 72.9 & 0.6 & 3.1 & 4.6 & 24.0 \\
\hline 05/29/2017 & 66.8 & 39.3 & 58.9 & 1.2 & 1.8 & 26.2 & 39.3 \\
\hline 06/01/2017 & 36.5 & 23.6 & 64.7 & 1.5 & 4.1 & 11.4 & 31.1 \\
\hline $06 / 02 / 2017$ & 28.4 & 15.9 & 55.9 & 0.9 & 3.2 & 11.6 & 40.9 \\
\hline $06 / 12 / 2017$ & 9.9 & 7.1 & 72.0 & 0.3 & 2.7 & 2.5 & 25.3 \\
\hline $06 / 22 / 2017$ & 21.0 & 1.5 & 7.1 & 0.1 & 0.5 & 19.4 & 92.4 \\
\hline 07/02/2017 & 21.6 & 13.2 & 61.0 & 1.1 & 4.9 & 7.4 & 34.1 \\
\hline Total & 466.7 & 276.4 & 52.9 & 11.2 & 2.2 & 179.0 & 44.9 \\
\hline
\end{tabular}
and interception loss (IL) in the study area 
losses in the rainfall events and subjected to a hierarchical cluster analysis. The optimum cut-off point for the formation of similarity groups was at 7 in the Euclidean distance, since a greater distance in similarity of rainfall events occurs from this group, resulting in the formation of three groups (Figure 2). The formation of groups shows the high temporal variability of the events, which is common in semi-arid regions (Ribeiro Filho et al., 2017).

According to the rainfall characteristics (Table 2), the intensities at intervals of 5 (I5), 10 (I10), 20 (I20), 30 (I30), 45 (I45), and 60 (I60) min presented higher differences than the other variables, differing statistically at the 0.01 significance level for all groups formed, whereas the other variables presented no statistical differences. This denotes the need for a detailed analysis of these variables to evaluate rainfall events and interception by plants, since the percentage of interception losses decreases with rain intensity (Giglio \& Kobiyama, 2013). The other variables presented maximums and minimums relatively close, and average near the medians, with good distribution.

The duration of the rainfall events presented the highest standard deviations for the three groups, directly affecting the other variables (TRD, ET $\mathrm{E}_{0}$ I, and $\mathrm{KE}$ ) (Table 2). The rainfall interval may increase the time required for the canopy to become completely wet and reestablish its water storage capacity, increasing interception losses (Dunkerley, 2008b; Carlyle-Moses et al., 2014).

The greatest interception losses were found in groups 1 and 3. These events showed the lowest kinetic energies and intensities, thus, the greater water retention in the vegetation allowed the evaporation. Sadeghi et al. (2015) evaluated modeling process for interception rainfall by plants in the semi-arid region of Iran and found higher interception losses with the lowest rainfall depths and duration in different rainfall groups.

None of the groups presented uniform throughfall due to the low intensities and varied redistribution of the rainfall by the forest canopy (Linhoss \& Siegert, 2016). The stemflow presented low percentages, usually lower than $5 \%$, in all events;

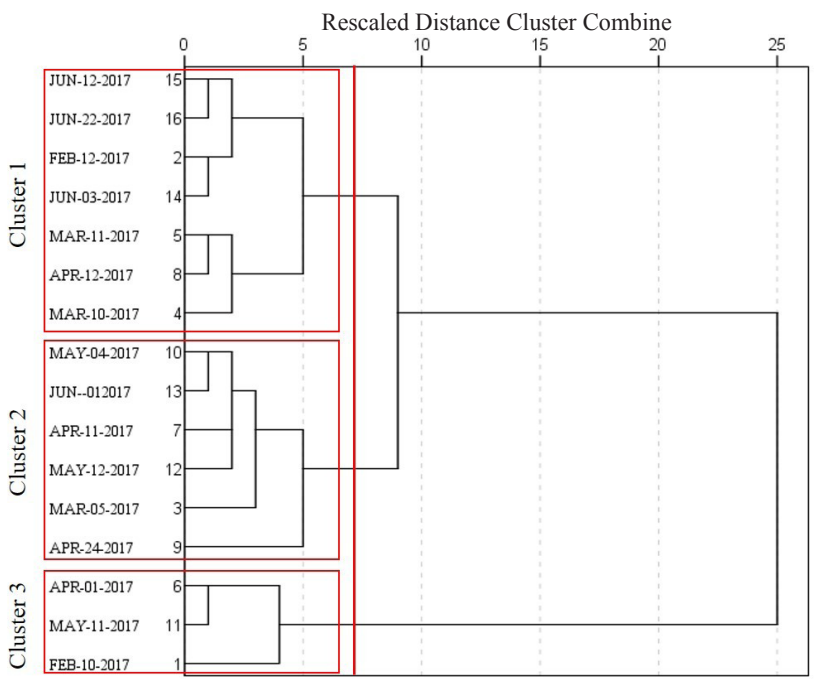

Figure 2. Hierarchical cluster analysis by the Ward's method for rainfall events in the study area in 2017
Table 2. Number of rainfall events, and mean, maximum, minimum, median, and standard deviation (SD) for the variables in each group of rainfall events

\begin{tabular}{|c|c|c|c|c|}
\hline Monitored & Variables & Cluster 1 & Cluster 2 & Cluster 3 \\
\hline \multirow{4}{*}{$\begin{array}{l}\text { TRD } \\
(\mathrm{mm})\end{array}$} & $\mathrm{N}^{0}$ of events & 7 & 6 & 3 \\
\hline & Mean & $13.64 \mathrm{a}$ & $25.04 a$ & $17.19 \mathrm{a}$ \\
\hline & Max and Min & 28.44 and 4.58 & 36.48 and 12.37 & 23.49 and 4.58 \\
\hline & Median and SD & 9.89 and 8.59 & 25.35 and 8.59 & 17.19 and 10.92 \\
\hline \multirow{4}{*}{$\begin{array}{c}\text { ETo } \\
\left(\mathrm{mm} \mathrm{d}^{-1}\right)\end{array}$} & $\mathrm{N}^{0}$ of events & 7 & 6 & 3 \\
\hline & Mean & $3.77 \mathrm{a}$ & $4.31 \mathrm{a}$ & $5.07 \mathrm{a}$ \\
\hline & Max and Min & 5.17 and 2.10 & 5.21 and 2.64 & 6.10 and 3.97 \\
\hline & Median and SD & 4.06 and 1.24 & 4.88 and 1.12 & 5.07 and 1.07 \\
\hline \multirow{4}{*}{$\begin{array}{l}\text { WS } \\
\left(\mathrm{m} \mathrm{s}^{-1}\right)\end{array}$} & $\mathrm{N}^{0}$ of events & 7 & 6 & 3 \\
\hline & Mean & $0.14 a$ & $0.07 a$ & $0.17 a$ \\
\hline & Max and Min & 0.40 and 0.02 & 0.12 and 0.01 & 0.28 and 0.07 \\
\hline & Median and SD & 0.13 and 0.13 & 0.09 and 0.05 & 0.17 and 0.11 \\
\hline \multirow{4}{*}{$\begin{array}{c}\mathrm{I} \\
\left(\mathrm{mm} \mathrm{h}^{-1}\right)\end{array}$} & $\mathrm{N}^{0}$ of events & 7 & 6 & 3 \\
\hline & Mean & $2.20 \mathrm{a}$ & $4.84 \mathrm{a}$ & $2.84 \mathrm{a}$ \\
\hline & Max and Min & 3.43 and 0.86 & 8.36 and 0.83 & 3.72 and 2.13 \\
\hline & Median and SD & 3.00 and 1.15 & 4.88 and 2.68 & 2.84 and 0.81 \\
\hline \multirow{4}{*}{$\begin{array}{c}\mathrm{T} \\
\text { (min) }\end{array}$} & $\mathrm{N}^{0}$ of events & 7 & 6 & 3 \\
\hline & Mean & $180.86 \mathrm{a}$ & $297.00 \mathrm{a}$ & $672.00 \mathrm{a}$ \\
\hline & Max and Min & 702.00 and 6.00 & 906.00 and 72.00 & 116.00 and 402.00 \\
\hline & Median and SD & 162.00 and 242.40 & 183.00 and 315.69 & 672.00 and 387.50 \\
\hline \multirow{4}{*}{$\begin{array}{c}\mathrm{KE} \\
\left(\mathrm{MJ} \mathrm{ha}^{-1} \mathrm{~mm} \mathrm{~h}^{-1}\right)\end{array}$} & $\mathrm{N}^{0}$ of events & 7 & 6 & 3 \\
\hline & Mean & $0.14 a$ & $0.17 a$ & $0.16 \mathrm{a}$ \\
\hline & Max and Min & 0.17 and 0.11 & 0.20 and 0.11 & 0.17 and 0.15 \\
\hline & Median and SD & 0.16 and 0.14 & 0.18 and 0.03 & 0.16 and 0.01 \\
\hline \multirow{4}{*}{$\begin{array}{c}15 \\
\left(\mathrm{~mm} \mathrm{~h}^{-1}\right)\end{array}$} & $\mathrm{N}^{0}$ of events & 7 & 6 & 3 \\
\hline & Mean & $15.43 b$ & $37.20 \mathrm{~b}$ & $184.80 \mathrm{a}$ \\
\hline & Max and Min & 43.20 and 3.60 & 64,80 and 14.40 & 234.00 and 108.00 \\
\hline & Median and SD & 7.20 and 16.06 & 36.00 and 17.59 & 184.80 and 67.38 \\
\hline \multirow{4}{*}{$\begin{array}{c}110 \\
\left(\mathrm{~mm} \mathrm{~h}^{-1}\right)\end{array}$} & $\mathrm{N}^{0}$ of events & 7 & 6 & 3 \\
\hline & Mean & $10.54 \mathrm{c}$ & $31.80 \mathrm{~b}$ & $106.80 \mathrm{a}$ \\
\hline & Max and Min & 28.80 and 1.80 & 59.40 and 14.40 & 117.00 and 97.20 \\
\hline & Median and SD & 3.60 and 11.40 & 30.60 and 15.39 & 106.80 and 9.91 \\
\hline \multirow{4}{*}{$\begin{array}{c}\mathrm{I15} \\
\left(\mathrm{mm} \mathrm{h}^{-1}\right)\end{array}$} & $\mathrm{N}^{0}$ of events & 7 & 6 & 3 \\
\hline & Mean & $7.71 \mathrm{C}$ & $27.60 \mathrm{~b}$ & $78.40 \mathrm{a}$ \\
\hline & Max and Min & 19.20 and 1.20 & 52.80 and 13.20 & 86.40 and 70.80 \\
\hline & Median and SD & 2.40 and 8.40 & 26.40 and 13.99 & 78.40 and 7.81 \\
\hline \multirow{4}{*}{$\begin{array}{c}120 \\
\left(\mathrm{~mm} \mathrm{~h}^{-1}\right)\end{array}$} & $\mathrm{N}^{0}$ of events & 7 & 6 & 3 \\
\hline & Mean & $6.04 \mathrm{c}$ & $23.40 \mathrm{~b}$ & $61.80 \mathrm{a}$ \\
\hline & Max and Min & 14.0 and 0.90 & 45.90 and 11.70 & 73.80 and 53.10 \\
\hline & Median and SD & 2.40 and 8.40 & 20.7 and 12.57 & 61.80 and 10.74 \\
\hline \multirow{4}{*}{$\begin{array}{c}130 \\
\left(\mathrm{~mm} \mathrm{~h}^{-1}\right)\end{array}$} & $\mathrm{N}^{0}$ of events & 7 & 6 & 3 \\
\hline & Mean & $4.11 \mathrm{c}$ & $18.40 \mathrm{~b}$ & $41.80 \mathrm{a}$ \\
\hline & Max and Min & 9.60 and 0,60 & 33.00 and 8.40 & 51.00 and 35.40 \\
\hline & Median and SD & 1.20 and 4.32 & 16.20 and 9.01 & 41.80 and 8.17 \\
\hline \multirow{4}{*}{$\begin{array}{c}145 \\
\left(\mathrm{~mm} \mathrm{~h}^{-1}\right)\end{array}$} & $\mathrm{N}^{0}$ of events & 7 & 6 & 3 \\
\hline & Mean & $2.85 \mathrm{c}$ & $12.97 b$ & $28.60 \mathrm{a}$ \\
\hline & Max and Min & 6.38 and 0.40 & 21.95 and 6.38 & 36.31 and 23.54 \\
\hline & Median and SD & 1.60 and 2.80 & 12.37 and 5.81 & 28.60 and 6.79 \\
\hline \multirow{4}{*}{$\begin{array}{c}160 \\
\left(\mathrm{~mm} \mathrm{~h}^{-1}\right)\end{array}$} & $\mathrm{N}^{0}$ of events & 7 & 6 & 3 \\
\hline & Mean & $2.19 \mathrm{C}$ & $9.95 b$ & $21.80 \mathrm{a}$ \\
\hline & Max and Min & 4.80 and 0.30 & 16.50 and 4.80 & $28.20 \mathrm{e}$ and 17.70 \\
\hline & Median and SD & 1.20 and 2.06 & 9.45 and 4.26 & 21.80 and 5.62 \\
\hline
\end{tabular}

TRD - Rainfall depth (mm); ET - Evapotranspiration (mm day $\left.{ }^{-1}\right)$; WS - Win speed $\left(\mathrm{m} \mathrm{s}^{-1}\right)$; I - Intensity $\left(\mathrm{mm} \mathrm{h}^{-1}\right)$; T - Duration of the events (min); KE - kinetic energy ( $\left.\mathrm{MJ} \mathrm{ha}^{-1} \mathrm{~mm}\right)$; 15 - Maximum intensity in $5 \mathrm{~min}\left(\mathrm{~mm} \mathrm{~h}^{-1}\right) ; 110$ - Maximum intensity in $10 \mathrm{~min}\left(\mathrm{~mm} \mathrm{~h}^{-1}\right)$; I15 - Maximum intensity in $15 \mathrm{~min}\left(\mathrm{~mm} \mathrm{~h}^{-1}\right)$; I20 - Maximum intensity in $20 \mathrm{~min}\left(\mathrm{~mm} \mathrm{~h}^{-1}\right)$; 130 - Maximum intensity in $30 \mathrm{~min}\left(\mathrm{~mm} \mathrm{~h}^{-1}\right) ; 145$ - Maximum intensity in $45 \mathrm{~min}\left(\mathrm{~mm} \mathrm{~h}^{-1}\right)$; 160 - Maximum intensity in $60 \mathrm{~min}\left(\mathrm{~mm} \mathrm{~h}^{-1}\right)$; Means followed by the same lowercase letters in the rows do not differ by the Tukey's test at 0.01 significance level

it was also reported for other semi-arid ecosystems by Levia \& Frost (2003). However, group 2, which presented the highest rainfall depths, showed the highest stemflow (SF), because the canopy was already saturated and the water that reached the surface of the leaves followed paths through branches to drain. Similar result was found by Lorenzon et al. (2013) when evaluating different stages of forests, with the highest SF for classes with higher precipitation depths.

The PCA applied to the variables (TRD, IL, ET, WS, I, T, KE, I5, I10, I20, I30, I45, and I60) was adequate by the KMO test with a value of 0.501 , denoting that the factorial model (PCA) can be applied to the data. The correlation matrix (Table 3 ) showed a good correlation (0.60) between IL and TRD because the vegetation water storage capacity is dependent on the total precipitation. Similar results were obtained by Thomaz \& Antoneli (2015), and Rodrigues et al. (2016). 
Table 3. Correlation matrix of variables related to the partitioning of rainfall by the vegetation

\begin{tabular}{|c|c|c|c|c|c|c|c|c|c|c|c|c|c|c|}
\hline & TRD & IL & Eto & WS & I & $T$ & KE & 15 & I10 & I15 & 120 & 130 & 145 & 160 \\
\hline TRD & 1.00 & & & & & & & & & & & & & \\
\hline IL & $\underline{0.60}$ & 1.00 & & & & & & & & & & & & \\
\hline Eto & $\overline{0.34}$ & 0.42 & 1.00 & & & & & & & & & & & \\
\hline WS & -0.45 & -0.44 & -0.25 & 1.00 & & & & & & & & & & \\
\hline I & 0.05 & -0.18 & -0.06 & -0.19 & 1.00 & & & & & & & & & \\
\hline $\mathrm{T}$ & -0.01 & -0.22 & 0.26 & $\underline{0.67}$ & -0.23 & 1.00 & & & & & & & & \\
\hline $\mathrm{KE}$ & -0.02 & -0.12 & -0.05 & $\overline{-0.07}$ & $\underline{0.93^{*}}$ & -0.19 & 1.00 & & & & & & & \\
\hline 15 & 0.13 & -0.11 & 0.18 & 0.16 & $\overline{0.06}$ & 0.40 & 0.17 & 1.00 & & & & & & \\
\hline 110 & 0.08 & -0.18 & 0.21 & 0.26 & 0.13 & 0.58 & 0.22 & $\underline{0.95^{\star}}$ & 1.00 & & & & & \\
\hline 115 & 0.06 & -0.21 & 0.24 & 0.31 & 0.18 & $\underline{0.67}$ & 0.25 & $\underline{0.87^{\star}}$ & $\underline{0.98^{*}}$ & 1.00 & & & & \\
\hline 120 & 0.04 & -0.22 & 0.25 & 0.32 & 0.18 & $\underline{0.71}$ & 0.24 & $\underline{0.82^{\star}}$ & $\underline{0.96^{*}}$ & $\underline{0.99 *}$ & 1.00 & & & \\
\hline 130 & 0.08 & -0.20 & 0.28 & 0.30 & 0.20 & $\overline{0.72}$ & 0.24 & $0.79^{\star}$ & $0.93^{*}$ & $0.98^{*}$ & $\underline{0.99 *}$ & 1.00 & & \\
\hline 145 & 0.06 & -0.20 & 0.30 & 0.30 & 0.22 & $\underline{0.72}$ & 0.24 & $\underline{0.76^{\star}}$ & $\underline{0.92^{\star}}$ & $\underline{0.97^{\star}}$ & $\underline{0.99^{*}}$ & $\underline{1.00^{*}}$ & 1.00 & \\
\hline 160 & 0.07 & -0.20 & 0.31 & 0.30 & 0.22 & $\underline{0.73}$ & 0.25 & $\underline{0.75^{\star}}$ & $\underline{0.91^{*}}$ & $\underline{0.97^{\star}}$ & $\underline{0.99 *}$ & $1.00^{\star}$ & $1.00^{*}$ & 1.00 \\
\hline
\end{tabular}

TRD - Rainfall depth (mm); interception loss (IL); ET - Evapotranspiration (mm d-1); WS - Wind speed ( $\left.\mathrm{m} \mathrm{s}^{-1}\right) ; \mathrm{I}$ - Intensity (mm h-1 $\mathrm{h}^{-1}$; - Duration of the event (min); KE - kinetic energy

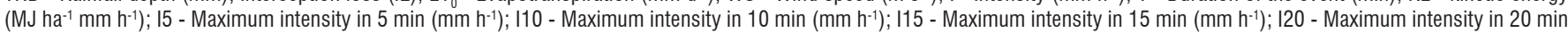

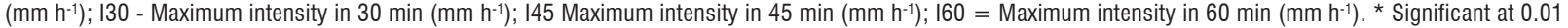

The maximum intensities of the I5, I10, I15, I20, I30, I45, and $\mathrm{I} 60 \mathrm{~mm} \mathrm{~h}^{-1}$ presented high correlations with each other, and with T. Although it is a derivation of the precipitated depth by the time, the high variability of the duration of the events caused no effect on the correlation between intensities and precipitated depth. Zhang et al. (2015) reported that the stemflow, throughfall, and interception loss increase with increasing intensity. Zhang et al. (2016) evaluated the interception of rainfall by shrubs in an arid region and found significant effects of I60 and rainfall depth on the interception loss.

The PCA resulted in three components accounting for $84.66 \%$ of the total variance of the data (Table 4 ). These components (PC1, PC2, and PC3) express the relationship between factors and variables and allow the identification of more interconnected variables in each component. The high factorial weights found indicate the most significant variables in each factor (Andrade et al., 2007).

Table 4. Matrix of the factorial weights of the variables in the main components after rotation by the Varimax algorithm

\begin{tabular}{|c|c|c|c|}
\hline \multirow{2}{*}{ Variables } & \multicolumn{3}{|c|}{ Components } \\
\hline & 1 & 2 & 3 \\
\hline 120 & 0.99 & 0.02 & 0.00 \\
\hline 115 & $\overline{0.99}$ & 0.04 & 0.01 \\
\hline 130 & $\overline{0.99}$ & 0.05 & -0.01 \\
\hline 145 & $\overline{0.99}$ & 0.05 & 0.00 \\
\hline 160 & $\overline{0.98}$ & 0.06 & 0.00 \\
\hline 110 & $\overline{0.96}$ & 0.07 & -0.01 \\
\hline 15 & $\overline{0.84}$ & 0.12 & -0.03 \\
\hline$T$ & $\overline{0.73}$ & -0.32 & -0.40 \\
\hline TRD & $\overline{0.04}$ & $\underline{0.77}$ & -0.28 \\
\hline WS & 0.37 & -0.76 & -0.08 \\
\hline IL & -0.24 & 0.71 & -0.42 \\
\hline ETo & 0.27 & 0.55 & -0.40 \\
\hline Int & 0.18 & 0.33 & $\underline{0.89}$ \\
\hline EC & 0.24 & 0.30 & 0.87 \\
\hline Eigenvalue & 7.36 & 2.31 & 2.18 \\
\hline Variance explained (\%) & 52.60 & 16.49 & 15.57 \\
\hline Cumulative Variance (\%) & 52.60 & 69.09 & 84.66 \\
\hline
\end{tabular}

TRD - Rainfall depth (mm); interception loss (IL); ET - Evapotranspiration (mm d-1 ); WS - Wind speed $\left(\mathrm{m} \mathrm{s}^{-1}\right) ; \mathrm{I}$ - Intensity $\left(\mathrm{mm} \mathrm{h}^{-1}\right) ; \mathrm{T}$ - Duration of the events (min); KE - kinetic energy $\left(\mathrm{MJ} \mathrm{ha}^{-1} \mathrm{~mm} \mathrm{~h}^{-1}\right)$; I5 - Maximum intensity in $5 \mathrm{~min}\left(\mathrm{~mm} \mathrm{~h}^{-1}\right) ; 110$ - Maximum intensity in $10 \mathrm{~min}\left(\mathrm{~mm} \mathrm{~h}^{-1}\right)$; I15 - Maximum intensity in $15 \mathrm{~min}\left(\mathrm{~mm} \mathrm{~h}^{-1}\right) ; 120$ - Maximum intensity in $20 \mathrm{~min}\left(\mathrm{~mm} \mathrm{~h}^{-1}\right) ; 130$ - Maximum intensity in $30 \mathrm{~min}\left(\mathrm{~mm} \mathrm{~h}^{-1}\right) ; 145$ - Maximum intensity in $45 \mathrm{~min}\left(\mathrm{~mm} \mathrm{~h}^{-1}\right) ; 160$ - Maximum intensity in $60 \mathrm{~min}\left(\mathrm{~mm} \mathrm{~h}^{-1}\right)$
PC1 was represented by the variables of maximum intensities (I5, I10, I15, I20, I30, and I45) and the duration of events and had factorial weights reaching 0.99 . These variables represent the energetic power of the rain in overcoming the physical barrier (vegetation) and explained more than $52.60 \%$ of the total variance. Figueiredo et al. (2016) evaluated a semi-arid region and reported the importance of the intensity, mainly I20 and I60 in explaining hydrological processes.

$\mathrm{TRD}, \mathrm{IL}$, and $\mathrm{ET}_{0}$ were interconnected forming PC2 and explained $16.49 \%$ of the variance. The high correlation between TRD and I showed the connection between the input water balance (TRD) and its outputs ( $\left.\mathrm{IL}+\mathrm{ET}_{0}\right)$ (Table 3$)$. The clustering of these variables in PC2 is related to the loss of continuity of rainfall events, characteristic in semi-arid regions (Dunkerley, 2008b). PC3 was formed by intensity, and kinetic energy and explained $15.57 \%$ of the total variation. Although these variables are connected to the energy of the rainfall events as $\mathrm{PC} 1$, they are based on the total duration of the event, explaining less the events because the rainwater stored by the canopy evaporates and saturates again during the same event (Dunkerley, 2008a; Zhang et al., 2016).

\section{Conclusions}

1. The vegetation showed interception of $44.9 \%$, throughfall of $52.9 \%$, and stemflow of $2.2 \%$ of the total rainfall.

2. The rainfall redistribution was different in each group formed by hierarchical cluster analysis.

3. The maximum rainfall intensities presented the highest factorial weights, denoting the importance of this variable in hydrological studies in the Brazilian semi-arid region.

4. The principal components PC1, PC2, and PC3 encompassed variables related to rainfall energy to overcome the vegetation physical barrier, inflow and outflow, and variables dependent on the rainfall duration, respectively.

\section{ACKNOWLedgements}

The authors thank the Brazilian Coordination for the Improvement of Higher Education Personnel for the financial support and scholarships granted to the authors. 


\section{Literature Cited}

Andrade, E. M. de; Araújo, L. de F. P.; Freitas, R. M. de; Gomes, R. B.; Lobato, F. O. Fatores determinantes da qualidade das águas superficiais na bacia do Alto Acaraú, Ceará, Brasil. Ciência Rural, v.37, p.1791-1797, 2007. https://doi.org/10.1590/S010384782007000600045

Brasil. Ministério da Integração Nacional. Secretaria de Políticas de Desenvolvimento Regional. Nova delimitação do semi-árido brasileiro. 2017. Available on: $<$ https://bit.ly/2DyMNun $>$. Access on: Jul. 2018.

Carlyle-Moses, D. E.; Lishman, C. E.; Mckee, A. J. A preliminary evaluation of throughfall sampling techniques in a mature coniferous forest. Journal of Forestry Research, v.25, p.407-413, 2014. https://doi.org/10.1007/s11676-014-0468-8

Dantas, N. B. de L. Estudo fitossociológico em encraves florestais na região serrana dos municípios de Portalegre e Martins - RN. Mossoró: UERN, 2016. 90p. Dissertação Mestrado

Dunkerley, D. Identifying individual rain events from pluviograph records: A review with analysis of data from an Australian dryland site. Hydrological Processes, v.22, p.5024-5036, 2008a. https://doi. org/10.1002/hyp.7122

Dunkerley, D. L. Intra-storm evaporation as a component of canopy interception loss in dryland shrubs: Observations from Fowlers Gap, Australia. Hydrological Processes, v.22, p.1985-1995, 2008 b. https://doi.org/10.1002/hyp.6783

EMPARN - Empresa de Pesquisa Agropecuária do Rio Grande do Norte. Monitoramento pluviométrico. 2017. Available on: <http://187.61.173.26/monitoramento/monitoramento.php $>$. Access on: Set. 2017.

Figueiredo, J. V. de; Araújo, J. C. de; Medeiros, P. H. A.; Costa, A. C. Runoff initiation in a preserved semiarid Caatinga small watershed, Northeastern Brazil. Hydrological Processes, v.30, p.2390-2400, 2016. https://doi.org/10.1002/hyp.10801

Giglio, J. N.; Kobiyama, M. Interceptação da chuva: Uma revisão com ênfase no monitoramento em florestas brasileiras. Revista Brasileira de Recursos Hídricos, v.18, p.297-317, 2013. https:// doi.org/10.21168/rbrh.v18n2.p297-317

Foster, G. R.; McCool, D. K.; Renard, K. G.; Moldenhauer, W. C. Conservation of the universal soil loss equation the SI metric units. Journal of Soil and Water Conservation, v.36, p.355-359, 1981.

Hargreaves, G. H.; Samani, Z. Reference crop evapotranspiration from temperature. Applied Engineering in Agriculture, v.1, p.96-99, 1985. https://doi.org/10.13031/2013.26773

IDEMA - Instituto de Desenvolvimento Sustentável e Meio Ambiente do Rio Grande do Norte. Perfil do seu município: Portalegre. 2008. Available on: <http://www.idema.rn.gov.br/contentproducao/ aplicacao/idema/socio_economicos/arquivos/Perfil\%202008/ Portalegre.pdf> Access on: Set. 2017.

Izídio, N. S. de C.; Palácio, H. A. de Q.; Andrade, E. M. de; Araújo Neto, J. R. de; Batista, A. A. Interceptação da chuva pela vegetação da caatinga em microbacia no semiárido cearense. Revista Agro@mbiente On-line, v.7, p.44-52, 2013.

Levia, D. F.; Frost, E. E. A review and evaluation of stemflow literature in the hydrologic and biogeochemical cycles of forested and agricultural ecosystems. Journal of Hydrology, v.274, p.1-29, 2003. https://doi.org/10.1016/S0022-1694(02)00399-2
Lima, P. R. A.; Leopoldo, P. R. Quantificação de componentes hidrológicos de uma mata ciliar, através do modelo de balanço de massas. Revista Árvore, v.24, p.241-252, 2000.

Linhoss, A. C.; Siegert, C. M. A comparison of five forest interception models using global sensitivity and uncertainty analysis. Journal of Hydrology, v.538, p.109-116, 2016. https://doi.org/10.1016/j. jhydrol.2016.04.011

Lloyd, C. R.; Marques, A. de O. Spatial variability of throughfall and stemflow measurements in Amazonian rainforest. Agricultural and Forest Meteorology, v.42, p.63-73, 1988. https://doi. org/10.1016/0168-1923(88)90067-6

Lorenzon, A. S.; Dias, H. C. T.; Garcia, L. H. Precipitação efetiva e interceptação da chuva em um fragmento florestal com diferentes estágios de regeneração. Revista Árvore, v.37, p.619-627, 2013. https://doi.org/10.1590/S0100-67622013000400005

Medeiros, P. H.; Araújo, J. C. de; Bronstert, A. Interception measurements and assessment of Gash model performance for a tropical semiarid region. Revista Ciência Agronômica, v.40, p.165-174, 2009.

Medeiros, S. R. M. de; Carvalho, R. G. de; Souza, L. di; Barbosa, A. H. da $\mathrm{S}$. Índice de qualidade das águas e balneabilidade do Riacho da Bica, Portalegre, RN, Brasil. Revista Ambiente \& Água, v.11, p.713-730, 2016.

Moita Neto, J. M.; Moita, G. C. Uma introdução à análise exploratória de dados multivariados. Química Nova, v.24, p.467-469, 1997.

Norusis, M. J. SPSS base system user's guide. Chicago: SPSS, 1990. $520 \mathrm{p}$.

Ribeiro Filho, J. C.; Palácio, H. A. de Q.; Andrade, E. M. de; Santos, J. C. N. dos; Brasil, J. B. Rainfall characterization and sedimentological responses of watersheds with different land uses to precipitation in the semiarid region of Brazil. Revista Caatinga, v.30, p.468-478, 2017. https://doi.org/10.1590/1983-21252017v30n222rc

Rodrigues, V. A.; Lucas-Borja, M. E.; Tarjuelo, J. M.; Canales, A. R.; Sánchez-Román, R. M. Interceptação da precipitação pelas copas em Pinus halepensis Mill- Albacete-Espanha. Irriga, v.21, p.736749, 2016. https://doi.org/10.15809/irriga.2016v21n4p736-749

Sadeghi, S. M. M.; Attarod, P.; Stan, J. T. van; Pypker, T. G.; Dunkerley, D. Efficiency of the reformulated Gash's interception model in semiarid afforestations. Agricultural and Forest Meteorology, v.201, p.76-85, 2015. https://doi.org/10.1016/j. agrformet.2014.10.006

Silva, D. C. da. Interceptação da chuva e escoamento superficial de água no solo no semiárido pernambucano. Serra Talhada: UFRPE, 2017. 59p. Dissertação Mestrado

Thomaz, E. L.; Antoneli, V. Rain interception in a secondary fragment of araucaria forest with Faxinal, Guarapuava-PR. Cerne, v.21, p.363-369, 2015. https://doi.org/10.1590/01047760201521031736

Zhang, Y. F.; Wang, X. P.; Hu, R.; Pan, Y. X.; Paradeloc, M. Rainfall partitioning into throughfall, stemflow and interception loss by two xerophytic shrubs within a rain-fed re-vegetated desert ecosystem, northwestern China. Journal of Hydrology, v.527, p.1084-1095, 2015. https://doi.org/10.1016/j.jhydrol.2015.05.060 Zhang, Z. S.; Zhao, Y.; Li, X. R.; Huang, L.; Tan, H. J. Gross rainfall amount and maximum rainfall intensity in 60-minute influence on interception loss of shrubs: A 10-year observation in the Tengger. Desert. Scientific Reports, v.6, p.1-10 2016. https://doi. org/10.1038/srep26030 